\title{
Need Assessment for Developing an Online English Proficiency Test Instrument in Higher Education During Covid-19 Pandemic
}

\author{
Asa Bani Putria, Wahyu Lestari \\ Universitas Negeri Semarang \\ E-mail address: asabanip@gmail.com
}

\begin{abstract}
This study aims to find out things needed to develop an online English proficiency test instrument in higher education during COVID-19 pandemic. The method of this study was descriptive qualitative method by using observation and interview as the data collection techniques. This study mention three main points that are needed in developing an online test instrument. The first is the system or application that will be used in conducting the online test. The second is the administrator of the online test. The last point is the device and facilities that support the online test.
\end{abstract}

Keywords: English proficiency test, online test, need assessment

In early 2020, a pandemic occurs due to Corona Virus Disease (COVID-19). It impacts all of daily aspects, including education. To prevent the spreading of this virus, Indonesian government issued a policy through the Circular of the Minister of Cultural Education No.3 of 2020. The policy affects the teaching learning process in academic community. A face-to-face learning is not allowed and it has to be substituted to an online learning. The policy also affects the test conducted during the teaching learning process.

One of the test affected is English proficiency test conducted in higher education. English proficiency test is one the important test for students in higher education. The test includes in one of the requirement for the students to graduate. Every university has their own standard to hold the test. There are so many models of the test that can be held. The universities usually conducts a paper based test which required the test takers to the room test and do the test together at one time. Because of the government policy during pandemic, a paper based test cannot be conducted. The test holder should think about the paper based test substitution so that the English proficiency test can be held during this pandemic. One of the solutions that can be done is by having an online test system. To have such an appropriate system, the test holder should analyze the things needed. Need assessment is the first step in conducting a research. It includes problem identification, condition analysis, and research team organization. The researcher observes, distributes questionnaires, and interviews the subject to get additional data (Kuntum An Nisa Imania, 2019).
There are several studies conducted relates to need assessment in developing test instrument. The first study conducted by Atim Rinawati (2017) aims to determine the extent of the need for teacher competency assessment in Kebumen regency. This study used qualitative method with interviews and documentation as the data collecting techniques. The results of this study state four conclusions that encourage the need for instrument development. The second study has some aims. One of them is to know the need of English teachers in developing authentic instruments at MAN 2 Bengkulu (Lismayanti, 2017). This study used cross-sectional survey method which collected data one by one at a time. This study concludes that the teachers have to learn more in developing their competence of education and in applying the evaluation with the curriculum. The third study was conducted by Febryna Nurhidayah (2016) which aims to know students' needs about problem-based worksheet, and the type of worksheet needed. The research methodology of this study was descriptive qualitative which used observation, interview, and questionnaire to obtain the data. Based on the results obtained, this study concludes that students need problem-based worksheet because they need to learn problem solving and find the solution.

The next study's purpose is to do need assessment on learning media, teaching materials, learning materials, worksheets, and learning evaluations used in the learning environment in schools and universities (Ilmi Zajuli Ichsan, 2019). The research method used is descriptive method with data collection techniques using observation and interviews. The study concludes 
that media learning, teaching materials, learning materials, worksheet students, and learning evaluations used are still not all HOTS-based. The last study aims to obtain information, describe the National Education Standards and the needs of students in a high school at Surakarta by developing the teaching materials (Elok Norma Khabibah, 2015). The research method used was survey method using validated questionnaire, interview, and documentation. This study concludes that the teaching materials used need to be developed according to scientific-based learning and authentic assessment (attitude, knowledge, and skills).

Based on the background mentioned, it is needed to have a need assessment in developing online English proficiency test instrument. Hence, the researcher can identify the needs to develop an appropriate online English proficiency test instrument.

\section{METHOD}

\section{Research Design}

This research used descriptive qualitative method. The method is able to describe the process over time in natural situations without the researcher's manipulation. It can reveal a reasonable relationship between the researcher and the research subject (Sutopo, 2002). This research was conducted in Center for International Language development in an Islamic Private University in Semarang. The research data were collected in two steps. They were observation and interview. Observation was done to obtain information about the previous test held in the institution. At this step, the researcher analyzed the test instrument used before pandemic. It includes the composition of the instrument, the sources used to compile the instrument, and how the test was conducted. Another step to collect the data was doing the interview. The researcher interviewed the management staffs of the institution. They were the secretary and one of the academic staff. The researcher asked several questions about the test that was conducted before pandemic and also the instrument used in the test. The researcher also asked about how the institution adapts during the pandemic and things they need so that the test continues. The data collection results were then analyzed to find the best solution to develop an appropriate online English proficiency test instrument.

\section{RESULTS AND DISCUSSION}

\section{Results}

The data were taken in two steps. They were observation and interview. The observation results relates to the English proficiency test held before pandemic. The test was held at a time with 20-60 test takers. It was conducted face to face in a room. The test was a paper based test which used computer answer sheet and pencil. The test instrument consisted of 140 multiple choice questions with four choices, from A to D. There were three parts of the questions. The questions were about English in daily life, academic, education, economics, literature, geography, history, biology, and so on.

The first was listening section which consisted of 50 questions. This section was divided into three parts. Questions number 1-30 were short dialogues. Questions number 31-38 were long conversations and the rest questions were talks. The test takers were asked to answer the questions based on the conversations or talks they heard. They should answer these questions in 30-35 minutes. The second section was structure and written expression. This section consisted of 40 questions which had to be answered in 25 minutes. This section was divided into two parts. The first 15 questions were asked the test takers to fill in the blank sentences. The last 25 questions were error recognition questions. The test takers should choose which the wrong word/phrase was. The last section was reading comprehension which consisted of 50 questions. In this section, the test takers were asked to answer the questions based on the passage. The questions consisted of five passages with ten questions for each passage. The test takers should answer all questions in 55 minutes. The test takers will take for about 120 minutes to do the test.

The correct answers were then converted based on the certain scale. Every section has their own conversion scale. The final score was obtained by adding up the conversion scores from each section and then divided by three.

The second data collection technique was interview. The researcher interviewed the secretary and the academic staff of the institution by asking 6 questions. Below are the questions and the transcript of the interview result: 
Table 1. Interview Transcript

\begin{tabular}{|c|c|c|}
\hline No. & Questions & Answers \\
\hline 1 & $\begin{array}{l}\text { What do you think about the English } \\
\text { proficiency test system at the } \\
\text { institution you worked for before } \\
\text { COVID-19 pandemic? }\end{array}$ & $\begin{array}{l}\text { Before the pandemic, the tests were carried out face- } \\
\text { to-face with a paper-based test system. Test takers } \\
\text { took the exam directly supervised by examiners. With } \\
\text { this examination system, the results obtained were } \\
\text { more objective because cheating can be minimized. } \\
\text { Hence, the test results showed the achievement of the } \\
\text { English proficiency comprehended by the test takers. }\end{array}$ \\
\hline 2 & $\begin{array}{l}\text { Do you think the system was doing } \\
\text { well? }\end{array}$ & $\begin{array}{l}\text { The system was well implemented. The test questions } \\
\text { were updated regularly and the face-to-face } \\
\text { examination system minimized the existence of } \\
\text { various cheats. The results obtained by the test takers } \\
\text { indicated the level of mastery of their English } \\
\text { proficiency. }\end{array}$ \\
\hline 3 & $\begin{array}{l}\text { What obstacles did you encounter } \\
\text { while using that system? }\end{array}$ & $\begin{array}{l}\text { The problem with paper-based-test system was the } \\
\text { duration of correction which took a long time because } \\
\text { it had to go through a scan of Computer Answer Sheet } \\
\text { and the process of scoring from the computer. In } \\
\text { addition, the question sheets had to be tightly stored to } \\
\text { avoid test question leakage. }\end{array}$ \\
\hline 4 & $\begin{array}{l}\text { How did you overcome those } \\
\text { obstacles? }\end{array}$ & $\begin{array}{l}\text { The staff strictly applied the standard operating } \\
\text { procedure of answer sheet correction process so the } \\
\text { sheets could be corrected according to the deadline. } \\
\text { The question sheets were also made in several series } \\
\text { to avoid question leakage. The staff should also } \\
\text { tighten up the questions' storage and distribution } \\
\text { systems. }\end{array}$ \\
\hline 5 & $\begin{array}{l}\text { What impact did the COVID-19 } \\
\text { pandemic have on the test system } \\
\text { that you have been implementing? }\end{array}$ & $\begin{array}{l}\text { During the pandemic, tests cannot be conducted face- } \\
\text { to-face and must be routed online. Online test are } \\
\text { conducted through an online test application and must } \\
\text { go through various trials to find the design and the } \\
\text { application that are the easiest to use. }\end{array}$ \\
\hline 6 & $\begin{array}{l}\text { What adjustments are needed to keep } \\
\text { your institution able to administer the } \\
\text { test during this pandemic? }\end{array}$ & $\begin{array}{l}\text { The staffs try out several online test applications, } \\
\text { create several question packages, and upload them to } \\
\text { the online test platform, diversify, and vary the } \\
\text { questions to minimize cheating, create online test } \\
\text { standard operating procedures, conduct online test } \\
\text { supervisor and administrator training, increase the } \\
\text { capacity and compatibility of the devices used for } \\
\text { online tests, collaborate with parties and related } \\
\text { institutions in developing and administering online } \\
\text { tests. }\end{array}$ \\
\hline
\end{tabular}

\section{Discussion}

A need assessment is very necessary to determine a field condition and a field need's change level. From the observation results, the things and staffs needed for conducting a paperbased test before pandemic are known. For conducting a test, the institution needs staffs with different job description. The first is a staff who sets all of the standard operating procedures for holding a test, start from the registration process to the test result announcement. The second is an administrator who is in charge in test takers registration and scheduling the tests. The administrator also archives the test result to the database. The third is a staff whose job is to compile test questions. The staff also prepares the things needed in holding a test. The staff chooses and prepares which question package used in the tests. The staff also prepares the computer answer sheets, and the stationary (pencils, erasers, and sharpeners) according to the number of the test takers registered. The next is the staff who is in charge as a supervisor or examiner during the test. The supervisor ensures that the test goes well in accordance with the standard operating procedure and the rules determined for the test. The last is a staff who is in charge in the process of scoring the test result. The staff is responsible for scanning the computer answer sheet and processing the final score of the test takers from the computer. The staff then announces the result through the institution's website and also give the result to the administrator to be archived.

The interview result supports the observation findings about the process of English proficiency test held before the pandemic. The interviewees stated that the paper-based test system was applied well as long as the responsible 
staffs do the job accordance with the standard operating procedure made. The institution also finds some obstacles in holding paper-based test. They are the time takes to process the test results. Sometimes, the institution has to hold a test with many test takers and the results have to be announce in a short time. Another obstacle found is that how to store the test question modules to prevent question leakage. The institution tries to minimize the obstacle by obeying the standard operating procedure and composing various kinds question modules periodically.

During COVID-19 pandemic, the institution has to postpone all of the scheduled tests due to the government policy that restricts social activities. The institution has to find a way to substitute the face-to-face test so that the test continues. The solution is that the institution has to substitute the face-to-face test to online test. There are many things considered to transfer the offline test to online. The online test procedures are similar to the face-to-face test but with many adjustments. The interviewees also stated the adjustments they need to develop an online test. They are the adjustments of standard operating procedures, the job description of the staffs on duty, the devices and the other facilities needed. The most important thing is to find the parties or institutions to help develop the system or application used in conducting the test so that the institution can hold an online test with similar system to the paper-based test or even better.

Based on the data analysis, needs to develop an online test can be seen as follow:

1) The system used in conducting the online test

The system needed should be able to be accessed anytime and anywhere by the users registered. The system can hold a paperless test with fast scoring process and easy test result archiving. The system used should cover at least three main menus. They are user account management, test question management, and test management. That statement is supported by the conclusion stated in a research by $\mathrm{Ni}$ Wayan Sumartini Saraswati (2015). Her research mentioned seven main menus created in her online test software. They are question group management, question management, test taker list management, test report management, $\log$ in, test work, and test result confirmation.

\section{a. User account management}

User account management can be divided into three, test taker account, administrator account, and super administrator account. In the test taker account, the test takers have an access to $\log$ in to the system with the username and password created, check the test schedule, do the test, and check the test result. The next is administrator account. This account can be used as test supervisor whose job is to monitor during the test. It can set the test schedule, recap the test takers' score, input and edit test questions. The last is super administrator account. This account has the same function as the administrator account. In addition, this account can create the test taker or administrator account. This finding is supported by a research conducted by Febrianto (2016). He concludes that there are three users who can access the online test application developed. They are administrators, teachers, and students.

The role of super administrator is important because $\mathrm{s} / \mathrm{he}$ creates the username and password for other user account. Username and password can be used as data security. Data security is an important element that must be considered in the design process of a system. A system without good data security will harm the system itself because the data will be freely accessed by irresponsible parties (Tristy Meinawati, 2013).

b. Test question management

The system used has to accommodate the model of the test questions usually used in the institution. The test model in the system should provide three sections of the test (listening section, structure and written expression, and reading comprehension). The system has to be able to process the score accordance with the criteria for each section. In this menu, the administration can input various test questions and group them into some series. The questions used in the test can be set randomly to prevent questions leakage and cheating. That statement is also supported by Kusworo (2010) who stated that question randomization can minimize cheating. The test questions that come out can be varied, dynamic, difficult to memorize and can reach all English skill tested (Fahmi, 2011).

\section{c. Test management}

The administrator account can set the test that will be conducted in this menu. The test setting process includes setting the test schedule, listing the test takers, choosing the test question used and the supervisor account in charge.

2) The job description of the staffs needed

The role of the staff is still needed although the test is conducted online by system. The staffs needed in the online test are similar to the staffs worked in the paper-based test. The first is the staff who set all of the standard operating 
procedure of the online test. It includes the pre-test procedure, the test procedure, and the post-test procedure. The second is the staff who takes care of the test taker registration process, the test taker account, and the test schedule. The last is the staff who is in charge as the test supervisor. This staff has to ensure that the test runs well and report the result of the test. The staff also troubleshoots the test takers who trouble with the system. All staffs who are in charge are given the access to the administrator account.

3) The device and facilities supported

As the test relates to the technology, the test holders and test takers have to prepare the devices that supports the system. The device needs is laptop or computer with the latest browser. Stable network and internet quota are also needed because a lot of trials have to be done to produce a good online test system. A research conducted by Farid (2012) supports this statement. He stated that a good system must be supported by an adequate technology both hardware and software.

\section{CONCLUSION}

After conducting the need assessment to develop an online test instrument, there are three things needed to be prepared to have an appropriate online test instrument. They are 1) the system/application used in conducting the online test, 2) the staffs in charge, and 3) the device and facilities supported.

\section{REFERENCES}

Atim Rinawati, N. K. (2017). Analisis Kebutuhan (Need Assessment) Pengembangan Instrumen Penilaian Kompetensi Kepribadian Guru di Kabupaten Kebumen. An-Nidzam, 4(2), 1-11

Elok Norma Khabibah, F. N. W., Yasinta Choirina, Sajidan. (2015). Analisis Kebutuhan Pengembangan Perangkat Pembelajaran Ditinjau dari Pemenuhan Standar Pendidik dan Ketuntasan Belajar Biologi SMA. Paper presented at the Seminar Nasional Pendidikan Sains, Surakarta.
Fahmi, A. (2011). Desain Model Sistem Ujian Online. Paper presented at the Seminar Nasional Teknologi Informasi \& Komunikasi Terapan, Semarang.

Farid, M. G. (2012). Analisis dan Perancangan Sistem Ujian Online di SMP Muhammadiyah 2 Godean. Naskah Publikasi, Sekolah Tinggi Manajemen Informatika dan Komputer AMIKOM Yogyakarta.

Febrianto. (2016). Pengembangan Sistem Ujian Online Berbasis Web pada Mata Pelajaran Teknik Listrik di Sekolah Menengah Kejuruan Yogyakarta. (Strata 1 Skripsi), Universitas Negeri Yogyakarta, Yogyakarta.

Febryna Nurhidayah, S. Z., Heru Kuswantoro. (2016). Analisis Kebutuhan Worksheet untuk Pembelajaran Berbasis Masalah di SMKN 2 Batu. Jurnal Pendidikan: Teori, Penelitian, dan Pengembangan, 1(7), 1224-1228.

Ilmi Zajuli Ichsan, D. V. S., Mieke Miarsyah. (2019). Environmental Learning Based on Higher Order Thinking Skills: A Needs Assessment. International Journal for Educational and Vocational Studies, 1(1), 21-24. doi:https://doi.org/10.29103/ijevs.v1i1.1389

Kuntum An Nisa Imania, S. K. B. (2019). Rancangan Pengembangan Instrumen Penilaian Pembelajaran Berbasis Daring. Jurnal PETIK, 5(1), 31-47.

Kusworo, A. P. (2010). Pembuatan Sistem Ujian Online. (Diploma III), Universitas Sebelas Maret,

Lismayanti, D. (2017). Analisis Kebutuhan terhadap Pengembangan Instrumen Penilaian Otentik di Madrasah Aliyah Negeri 2 Kota Bengkulu. Manhaj, 1(1), 1-14.

Ni Wayan Sumartini Saraswati, D. M. D. U. P. (2015). Sistem Ujian Online Berbasis Website. Jurnal S@CIES, 6(1),21-29.

Sutopo, H. B. (2002). Metodologi Penelitian Kualitatif. Surakarta: Universitas Sebelas Maret Press.

Tristy Meinawati, K. I. S., Oky Dwi Nurhayati. (2013). Perancangan Aplikasi Ujian Online Jurusan Sistem Komputer Universitas Diponegoro. Jurnal Teknologi dan Sistem Komputer, 1(4), 169-178.

doi:https://doi.org/10.14710/jtsiskom.1.4.201 $\underline{3.169-178}$ 